\title{
外ダイアフラム形式角形鋼管柱梁接合部の耐力に関する理論的・実験的研究 THEORETICAL AND EXPERIMENTAL STUDY ON STRENGTH OF RHS-COLUMN TO BEAM CONNECTIONS WITH EXTERIOR DIAPHRAGM
}

\author{
松尾 真太朗*, 田中 剛**, 井上一 朗*** \\ Shintaro MATSUO, Tsuyoshi TANAKA and Kazuo INOUE
}

\begin{abstract}
This paper addresses the derivation of collapse load of rectangular hollow sections (RHS)-column to beam connections with exterior diaphragm based on the method of plastic analysis. The presented formulae are available for arbitrary shapes of exterior diaphragms, and include the influence of weld details between the diaphragms and the column. In order to verify the validity of the collapse load, tests of the connections were performed. Major findings from the tests are summarized as follows: (1) the yield strength obtained from the tests was about 70 to $80 \%$ of the collapse loads, (2) there were 14 to $45 \%$ differences between the experimental maximum strength and the calculated maximum strength, (3) the experimental maximum strength of specimens which were expected to fracture in the fillet weld between RHS-column and exterior diaphragm agreed well with the calculated maximum strength, and (4) the assumed collapse mechanisms agreed well with the ultimate states of the connections.
\end{abstract}

Keywords : exterior diaphragm, RHS-column, plastic analysis, collapse load, tensile test, fillet weld 外ダイアフラム, 角形鋼管柱, 塑性解析, 崩壊荷重, 引張実験, 隅肉溶接

1. はじめに

角形鋼管柱と鉄骨梁からなる接合部の主な形式として,通しダイアフ ラム, 内ダイアフラム, 外ダイアフラムがある. 外ダイアフラム形式に は, 加工工程や溶接量が少ないため施工性, 経済性などを向上させられ るという利点がある.また 1995 年に発生した兵庫県南部地震の被害と して角形鋼管柱梁接合部の完全溶込溶接部付近での柱や梁フランジの破 断の発生が数多く観察された1)が, このような破壊を防止する方法とし て柱貫通形式である外ダイアフラム形式を採用することは有効な手段で あると考えられる。

しかし外ダイアフラム形式の柱梁接合部では,鋼管壁の局部変形が無 視できないため, 接合部の剛性·耐力を確保するためには, 外ダイアフ ラムの形状・法の設計に十分な配虑が必要となる．剛性に関しては， 山成ら ${ }^{2)}$, 上場ら ${ }^{32}$ にる数值実験から得られた接合部の復元力特性モ デル, 耐力に関しては, 田渕ら 4),5による接合部の局部破壊耐力推定式, 森田ら娄による降伏線理論に基づく接合部の全塑性耐力などが挙げられ る.

本論では，図1(a)に示す形状の外ダイアフラムを対象として，接合 部の降伏耐力と最大耐力の評価に主眼を置いている.外ダイアフラム形 式接合部の許容耐力を与えているものに文献 7)がある。ここで採用さ れている耐力式は文献 4),5)に基づくものであり，図1(b)に示す外ダイ

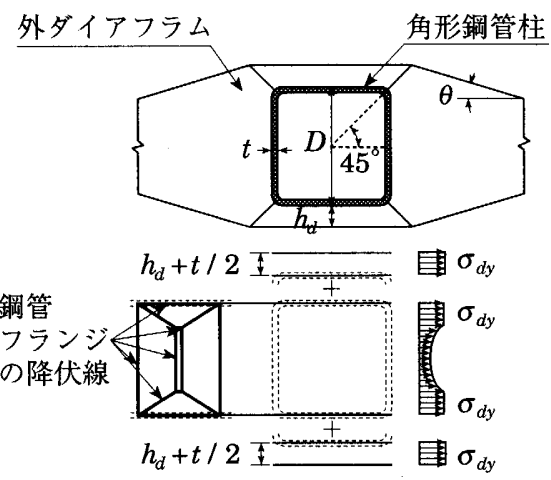

(b) 文献 4) 6)

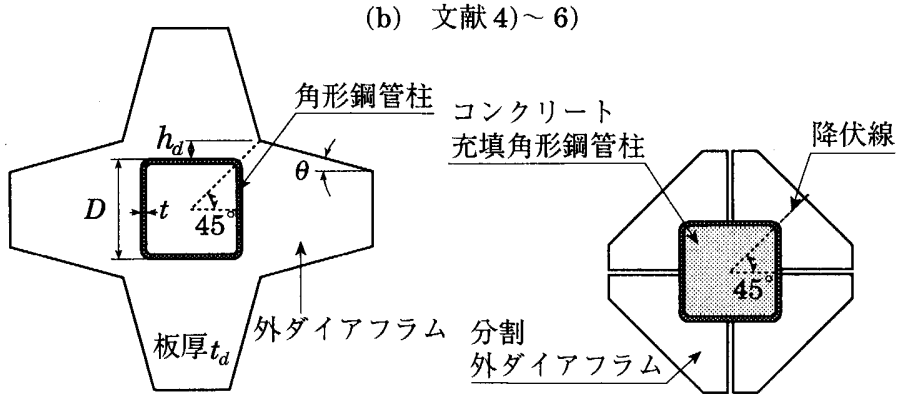

(a) 本論で対象とする形状

(c) 文献 8)

\footnotetext{
本論文の一部は，日本建築学会近畿支部研究報告集 (2005年 6 月)，およU゙日本建築学会大会学術講演梗概集 (2005年 9 月)に発表している

* 京都大学大学院工学研究科建築学専攻 大学院生 $\quad$ Graduate Student, Dept. of Architecture and Architectural Engineering, Kyoto

** 神戸大学工学部建設学科 助教授・博士 (工学)

*** 京都大学大学院工学研究科建築学専攻 教授・工博 University

Assoc. Prof., Dept. of Architecture and Civil Engineering, Kobe University, Dr. Eng. Prof., Dept. of Architecture and Architectural Engineering, Kyoto University, Dr. Eng.
} 
アフラムを単調引張載荷を行い, 接合部の局部破壊に関係する各寸法因 子の影響を回帰分析の手法を用いて定量的に評価したものである.しか し，この耐力式の適用には接合部寸法に関する制限がある。具体的に は，鋼管外径を $D$, 鋼管板厚を $t$, 外ダイアフラムせいを $h_{d}$, 外ダイア フラム板厚を $t_{d}$, 水平ハンチ角度を $\theta$ とした場合に, $17 \leq D / t \leq 67$, $h_{d} / D \leq 0.4,0.75 \leq t_{d} / t \leq 2.0, \theta \leq 30^{\circ}$ という制限が設けられている. さらに文献 7)では，角形䤡管柱と外ダイアフラムの溶接部の設計に関 して記述されていない．また文献6)では，外ダイアフラム形式柱梁接 合部に対して図 1(b)に示す崩壊機構を用いて耐力式を与えているが， この耐力式によれば上界定理に基づいて試行計算により耐力の最小値を

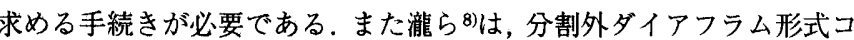
ンクリート充填角形鋼管柱梁接合部（図 1(c)）の降伏耐力の算定方法と して，銅管中心から 45 度方向の外ダイアフラム断面に降伏線を仮定し ているが，過大評価を与えている可能性がある.

そこで本論では，溶接接合部も含めた任意の接合部寸法に対して適用 できる耐力式を，図 1(a)に示す外ダイアフラムに対して構築する，具体 的には，地霞時の柱一引張側梁フランジ接合部における崩壊機構を仮定 し，それに基づく崩壊荷重を誘導する．さらに，崩懐荷重と崩壊機構の 妥当性の検証を目的として，外ダイアフラム形式の角形鋼管柱と引張側 梁フランジの接合部を取り出した試験体を対象に局部引張実験を行う.

\section{2. 崩壤荷重の誘道}

\section{1 塑性解析モデル}

本論では,中柱の柱梁接合部に地震時水平荷重時応力が作用する場合 を対象としている.中柱の柱梁接合部に作用する地震時水平荷重時応力 は図2左図のように表される。このとき外ダイアフラムに作用する応力 は，角形鎆管柱を挟んで逆対称に分布するものと考える。この場合，接 合部の引張側と圧縮側の応力は同じ分布を示すが,外ダイアフラムと角 形鋼管柱との隅肉溶接接合部については，引張側で検討する必要があ る、そこで本論では，引張側だけを検討の対象とする，なお，圧縮時に 外ダイアフラムが座屈する場合の耐力評価に関しては本論の対象外とす る. 接合部の引張側を図2右図のようにモデル化する. 図2右図に示す ように荷重方向と直交する角形鋼管柱の中心線に位置する外ダイアフラ 厶断面を無応力状態と考え, 以下の塑性解析では図2右図に示す塑性解 析モデルを用いる。

\section{2 崩壤機構 1}

崩壊機構 1 として, 図 3 に示す機構を仮定する。これは, 銅管フラン ジの面外崩壊機構 (図4参照) と鋼管フランジから水平ハンチ部にかけ て形成される外ダイアフラムの降伏場からなる崩壊機構である．図 3 は, 梁フランジ幅 $B_{f}$ が外ダイアフラム幅 $B_{d}$ に比べて小さい接合詳細 (3 章で述べるNo.10試験体のような形状に相当）にも対応できるように， $B_{f}<B_{d}$ の場合について示している.

\subsection{1 応力仕事}

外ダイアフラム形式角形鋼管柱梁接合部が梁フランジから引張荷重を 受ける場合に,鋼管角部から水平ハンチ部にかけて外ダイアフラムを一 様歪の三角形要素に分割し，それぞれの領域（以下，領域 I, II, III と 呼ぶ）が降伏状態にあるものと考える (図 3 参照)。三角形要素 $m$ にお ける変位関数 ${ }_{m} u,{ }_{m} v$ は, 一般化座標 ${ }_{m} \alpha_{1}, \ldots,{ }_{m} \alpha_{6}$ を用いると次式で 表される9．ただし，領域 $m$ を前下付き文字で表す。

$$
{ }_{m} u==_{m} \alpha_{1}+_{m} \alpha_{2} x+_{m} \alpha_{3} y
$$

$$
{ }_{m} v=_{m} \alpha_{4}+_{m} \alpha_{5} x+{ }_{m} \alpha_{6} y
$$

$3 \supset$ 節点番号を $j, k, l$ （反時計回りに $j, k, l)$ とし, 各節点座標を $x_{j}, y_{j}$ などで表し, 各節点変位を $u_{j}, v_{j}$ などで表すと, ${ }_{m} \alpha_{1}, \ldots,{ }_{m} \alpha_{6}$ は次 式で表される。

$$
\begin{aligned}
& \left.{ }_{m} \alpha_{1}=\left\{\left(x_{k} y_{l}-x_{l} y_{k}\right) u_{j}+\left(x_{l} y_{j}-x_{j} y_{l}\right) u_{k}+\left(x_{j} y_{k}-x_{k} y_{j}\right) u_{l}\right\}\right]_{m} A \\
& \left.{ }_{m} \alpha_{2}=\left\{\left(y_{k}-y_{l}\right) u_{j}+\left(y_{l}-y_{j}\right) u_{k}+\left(y_{j}-y_{k}\right) u_{l}\right\}\right\}_{m} A \\
& \left.{ }_{m} \alpha_{3}=\left\{\left(x_{l}-x_{k}\right) u_{j}+\left(x_{j}-x_{l}\right) u_{k}+\left(x_{k}-x_{j}\right) u_{l}\right\}\right\}_{m} A \\
& \left.{ }_{m} \alpha_{4}=\left\{\left(x_{k} y_{l}-x_{l} y_{k}\right) v_{j}+\left(x_{l} y_{j}-x_{j} y_{l}\right) v_{k}+\left(x_{j} y_{k}-x_{k} y_{j}\right) v_{l}\right\}\right]_{m} A \\
& { }_{m} \alpha_{5}=\left\{\left(y_{k}-y_{l}\right) v_{j}+\left(y_{l}-y_{j}\right) v_{k}+\left(y_{j}-y_{k}\right) v_{l}\right\} /_{m} A \\
& \left.{ }_{m} \alpha_{6}=\left\{\left(x_{l}-x_{k}\right) v_{j}+\left(x_{j}-x_{l}\right) v_{k}+\left(x_{k}-x_{j}\right) v_{l}\right\}\right\}_{m} A
\end{aligned}
$$

ここで, ${ }_{m} A$ は領域 $m$ の面積の 2 倍を表す.

${ }_{m} \varepsilon_{x}$ ( $x$ 方向の歪) ${ }_{m} \varepsilon_{y}\left(y\right.$ 方向の歪), ${ }_{m} \gamma_{x y}$ (面内せん断歪) は(3.a c) 式 で表されるので, ${ }_{m} \varepsilon_{x},{ }_{m} \varepsilon_{y},{ }_{m} \gamma_{x y}$ は(4.a c)式で与えられる.

$$
\begin{aligned}
& { }_{m} \varepsilon_{x}=\partial_{m} u / \partial x,{ }_{m} \varepsilon_{y}=\partial_{m} v / \partial y,{ }_{m} \gamma_{x y}=\partial_{m} u / \partial y+\partial_{m} v / \partial x \\
& { }_{m} \varepsilon_{x}={ }_{m} \alpha_{2},{ }_{m} \varepsilon_{y}={ }_{m} \alpha_{6},{ }_{m} \gamma_{x y}={ }_{m} \alpha_{3}{ }_{m} \alpha_{5}
\end{aligned}
$$

一方,次式で表されるMisesの降伏条件および塑性流れの法線則を用い ると ${ }_{m} \varepsilon_{x},{ }_{m} \varepsilon_{y},{ }_{m} \gamma_{x y}$ は $(6 . \mathrm{a} \sim \mathrm{c})$ 式で表される。

$$
\Phi={ }_{m} \sigma_{x-m}^{2} \sigma_{x m} \sigma_{y}+_{m} \sigma_{y}^{2}+3_{m} \tau_{x y}^{2}-\sigma_{d y}^{2}=0
$$

${ }_{m} \varepsilon_{x}=\lambda\left(2_{m} \sigma_{x}-_{m} \sigma_{y}\right){ }_{m} \varepsilon_{y}=\lambda\left({ }_{m} \sigma_{x}+2_{m} \sigma_{y}\right){ }_{m} \gamma_{x y}=6 \lambda_{m} \tau_{x y} \quad(6 . \mathrm{a} \sim \mathrm{c})$

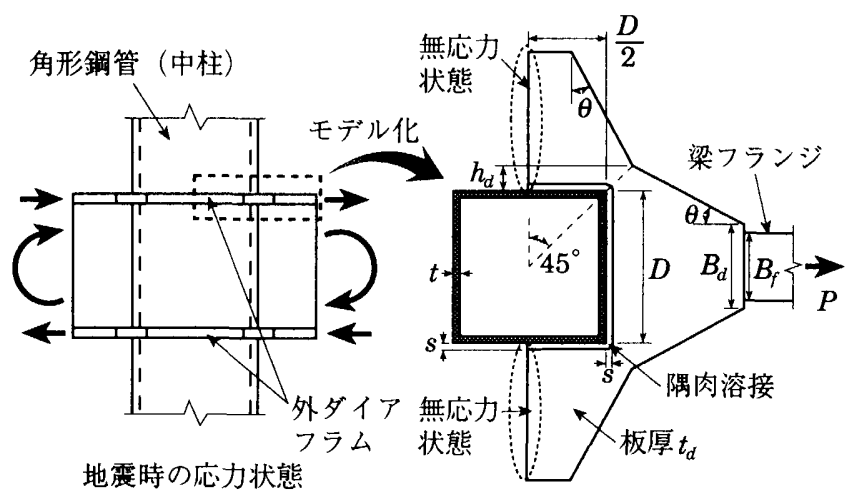

図 2 塑性解析モデル

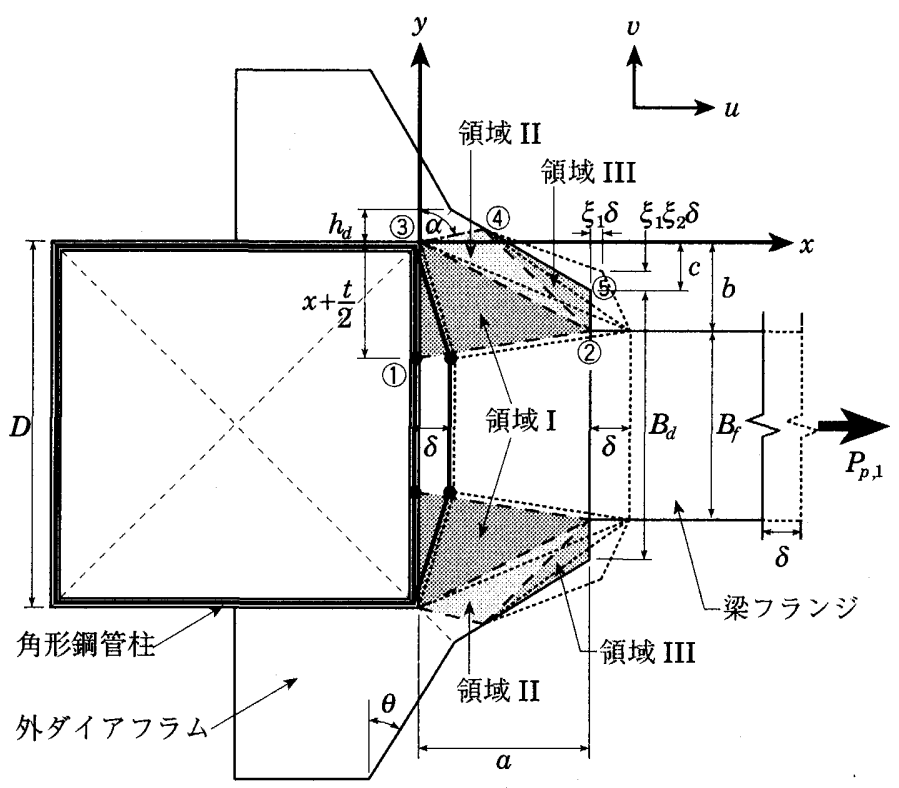

図 3 一様歪の三角形要素と接合部の崩壊機構 1 
ここで, ${ }_{m} \sigma_{x}: x$ 方向の応力, ${ }_{m} \sigma_{y}: y$ 方向の応力, ${ }_{m} \tau_{x y}:$ せん断応力, $\sigma_{d y}:$ 外ダイアフラムの降伏応力, $\lambda$ : 非負の比例係数である. (4.a c), (6.a c) 式より, 領域 $m$ における応力と歪が求まるので, 領域 $m$ の応力仕事 ${ }_{m} W_{i n}$ は次式で表される.

$$
{ }_{m} W_{i n}=\int_{m}\left({ }_{m} \sigma_{x} \cdot{ }_{m} \varepsilon_{x}+{ }_{m} \sigma_{y} \cdot{ }_{m} \varepsilon_{y}+{ }_{m} \tau_{x y} \cdot{ }_{m} \gamma_{x y}\right) d V
$$

以下, 図 3 の領域 I, II, III に扔ける応力仕事を誘導する.

まず，図3に示すように各領域の節点番号を1〜 5とする.このとき， 各節点座標および節点変位を以下のように設定する。

$$
\begin{aligned}
& x_{1}=x_{3}=0, x_{2}=x_{5}=a, x_{4}=l_{d} \sin \alpha \\
& y_{1}=-(x+t / 2), y_{2}=-b, y_{3}=0, y_{4}=l_{d} \cos \alpha, y_{5}=-c \\
& u_{1}=u_{2}=\delta, u_{3}=u_{4}=0, u_{5}=\xi_{1} \delta \\
& v_{1}=v_{2}=v_{3}=v_{4}=0, v_{5}=\xi_{1} \xi_{2} \delta
\end{aligned}
$$

ここで， $a, b, c$ : 図 3 を参照, $l_{d}$ ：線分 3-4 の長さ ((9)式参照，ただし， $\theta$ :

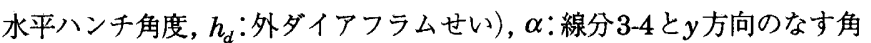
度, $\delta$ : 荷重方向 $(x$ 方向 $)$ へ仮想変位, $\xi_{1}, \xi_{2}$ : 比例係数 $\left(0 \leq \xi_{1} \leq 1\right), x$ : 鋼管フランジの面外変形を決定づけるパラメー夕, $t:$ 鋼管板厚である.

$$
l_{d}=\{(1+\tan \theta) /(\cos \alpha+\tan \theta \cdot \sin \alpha)\} h_{d}
$$

\section{(a) 領域।の忍力仕事}

(2),(4),(8)式より領域 Iの歪を,(5),(6)式より領域 I の応力を求 め, それらを(7)式に代入することにより, 領域 I の応力仕事 ${ }_{I} W_{d}$ は次 式で得られる。

$$
{ }_{1} W_{d}=2\left\{\frac{(x+t / 2-b)^{2}+a^{2} / 4}{3}\right\}^{0.5} t_{d} \sigma_{d y} \delta
$$

ここで, $t_{d}:$ 外ダイアフラム板厚である.

\section{(b) 領域 Iの応力仕事}

領域 I の場合と同様の手続きを行うことにより, 領域 II の応力仕事 ${ }_{\text {II }} W_{d}$ は次式で得られる.

$$
{ }_{\mathrm{II}} W_{d}=2\left\{\frac{1+\left(\tan ^{2} \alpha\right) / 4}{3}\right\}^{0.5} \cos \alpha \cdot l_{d} t_{d} \sigma_{d y} \delta
$$

(c) 領域 IIIの応力仕事

図 3 より領域 III は 3 辺のうち 2 辺の変形拘束が 0 であるため, 領域 III の応力仕事 ${ }_{\mathrm{III}} W_{d}$ の最小值は非常に小さいものと考えられる. そこで

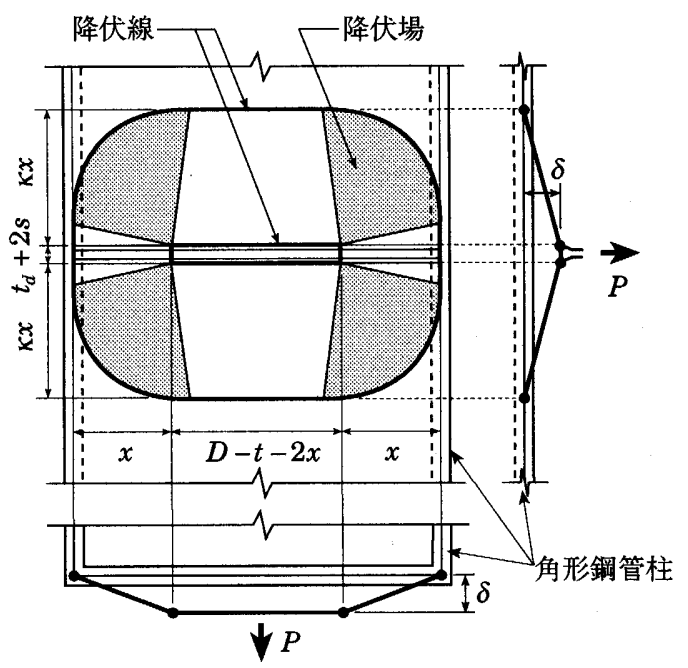

図 4 鋼管フランジの面外崩壊機構
本論では ${ }_{\mathrm{III}} W_{d}$ を無視する. ${ }_{\mathrm{III}} W_{d}$ を無視することの妥当性については付録 Aを参照のこと.

(d) 鋼管フランジの心力仕事

鋼管フランジの応力仕事 $W_{c}$ に関しては, 図 4 に示す面外崩壊機構を 仮定することにより，次式で得られる ${ }^{10)}$.

$$
W_{c}=\left\{\frac{t_{d}+2 s}{x}+\frac{D-t}{\kappa \cdot x}-\frac{2}{\kappa}+\frac{4}{\pi}\left(\log _{e} \kappa\right)^{2}+\pi\right\} \sigma_{c y} t^{2} \delta
$$

ここで, $s:$ 溶接脚長, $D:$ 鋼管外径, $\kappa:$ 鋼管フランジの面外変形を決 定づけるパラメー夕, $\sigma_{c y}$ : 鋼管フランジの降伏応力である.

\subsection{2 崩壊荷重}

前項の結果から，接合部の応力仕事 $W_{i n}$ は次式で得られる.

$$
W_{\text {in }}=W_{1} W_{d}+W_{d}+W_{c}
$$

外力を $P$ とすると外力仕事は $W_{e x}=P \delta$ となるので, 仮想仕事の原理よ り接合部の崩壊荷重 $P_{p, 1}$ は次式で得られる.

$$
P_{p, 1}=\left({ }_{I} W_{d}+{ }_{I I} W_{d}+W_{c}\right) / \delta
$$

上式の最小值を得るために次式を満足する $x, \kappa, \alpha$ を求める必要がある.

$$
\frac{\partial P_{p, 1}}{\partial x}=0, \frac{\partial P_{p, 1}}{\partial \kappa}=0, \frac{\partial P_{p, 1}}{\partial \alpha}=0
$$

上式から次のような関係が得られる.

$$
\begin{aligned}
t_{d} \sigma_{d y}\left\{12(x+t / 2-b)^{2}+3 a^{2}\right\}^{-0.5}( & x+t / 2-b) \\
& -\sigma_{c y} t^{2}\left\{t_{d}+2 s+(D-t) / \kappa\right\} / 4 x^{2}=0
\end{aligned}
$$$$
2\left(\pi+4 \kappa \log _{e} \kappa\right) x-(D-t) \pi=0
$$$$
\alpha=\tan ^{-1}(4 \tan \theta)
$$

(16.a c)式より得られる $x, \kappa, \alpha を(14)$ 式に代入すると, $P_{p, 1}$ は次式で表 される.

$$
\begin{aligned}
P_{p, 1}= & 2\left[\left\{\frac{(x+t / 2-b)^{2}+a^{2} / 4}{3}\right\}^{0.5}+\left(\frac{1+\left(\tan ^{2} \alpha\right) / 4}{3}\right)^{0.5} \cos \alpha \cdot l_{d}\right] \sigma_{d y} \cdot t_{d} \\
& +\left\{\frac{t_{d}+2 s}{x}+\frac{D-t}{\kappa \cdot x}-\frac{2}{\kappa}+\frac{4}{\pi}\left(\log _{e} \kappa\right)^{2}+\pi\right\} \sigma_{c y} \cdot t^{2}
\end{aligned}
$$

\section{3 崩壊機構 2 と崩壞機構 3}

崩壊機構 2 として，図 5(a)に示す機構を仮定する。これは，鋼管つ ランジの面外崩壊機構（図 4 参照), 鋼管角部から水平ハンチ部にかけ て形成される外ダイアフラムの降伏線 (以下, 斜方降伏線) および前面 隅肉溶接部の降伏領域 (鋼管フランジが面外変形する範囲) からなる崩 壊機構である。崩壊機構 3 として, 図 5(b)に示す機構を仮定する。こ れは, 鋼管フランジの面外崩壊機構（四 4 参照）, 前面隅肉溶接部の降 伏領域 (鋼管フランジが面外变形する範囲)および側面隅肉溶接部の降

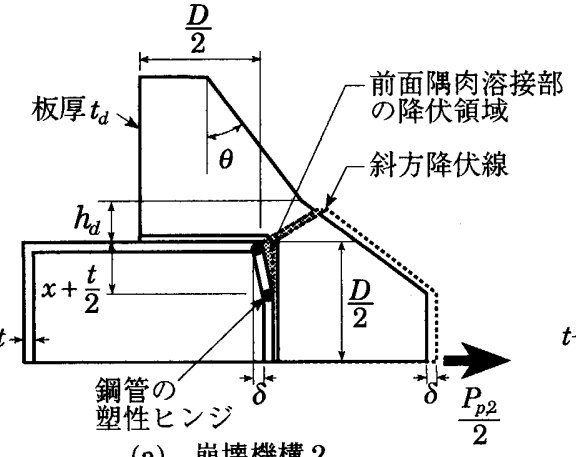

(a) 崩壊機構 2

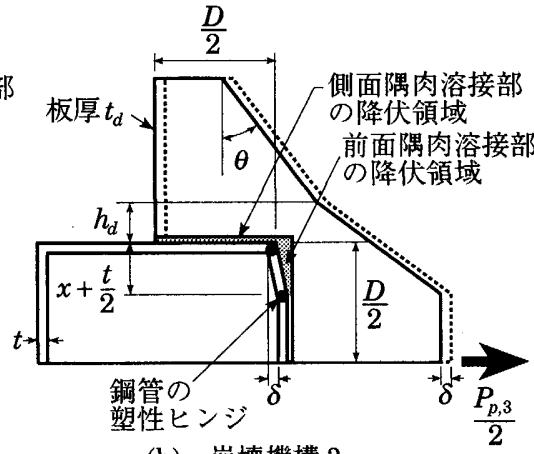

(b) 崩壊機構 3
図 5 接合部の崩壊機構 
伏領域からなる崩壊機構である。

\subsection{1 応力仕事}

鋼管フランジの応力仕事は(12)式で与えられるので，以下，斜方降 伏線でなされる応力仕事と前面および側面隅肉溶接部でなされる応力仕 事を誘導する。

\section{(a) 斜方降伏線でなされる応力仕事 $W_{d}$}

斜方降伏線が形成される部分を拡大して図6に示す，図6より $W_{d}$ は 次式で表される.

$$
W_{d}=2\left(\sigma_{n} \cos \beta+\tau_{n t} \sin \beta\right) l_{d}^{\prime} \cdot t_{d} \cdot \delta
$$

ただし，上式において，

$$
l_{d}{ }^{\prime}=\{(1+\tan \theta) /(\cos \beta+\tan \theta \cdot \sin \beta)\} h_{d}
$$

ここで, $\sigma_{n}:$ 図 6 の $n$ 軸方向の垂直応力, $\tau_{n t}: t$ 軸方向のせん断応力, $\beta$ : 斜方降伏線と荷重軸に垂直な方向とのなす角度, $l_{d}{ }^{\prime}$ : 斜方降伏線の長さ である. Misesの降伏条件と塑性流れの法線則を適用すると, $\sigma_{n}, \tau_{n t}$ は 次式で表される.ただし, $t$ 軸方向の拘束は小さいと考え, $t$ 軸方向の垂 直応力は 0 とする。

$$
\sigma_{n}=\left(\frac{3}{3+\tan ^{2} \beta}\right)^{0.5} \sigma_{d y}, \tau_{n t}=\frac{\tan \beta}{\left\{3\left(3+\tan ^{2} \beta\right)\right\}^{0.5}} \sigma_{d y}
$$

(20.a,b)式を(18)式に代入して $W_{d}$ が次式で得られる.

$$
W_{d}=2 \sigma_{d y} \cdot t_{d} \cdot h_{d}\left(\frac{3+\tan ^{2} \beta}{3}\right)^{0.5} \frac{1+\tan \theta}{1+\tan \theta \cdot \tan \beta} \delta
$$

(b) 前面隅肉溶接部でなされる応力仕事 $W_{f w}$

図 $5(\mathrm{a}),(\mathrm{b})$ より前面隅肉溶接部は長さ $x+t / 2$ にわたって塑性化するの で, 単位長さあたりの降伏耐力を $f_{w} q_{y}{ }^{11)}$ とすると $W_{f w}$ は次式で表される.

$$
W_{f w}=2_{f w} q_{y}(x+t / 2) \delta
$$

ただし，上式において，

$$
{ }_{f w} q_{y}=2 \sigma_{w y} \cdot s / \sqrt{15}
$$

\section{ここで, $\sigma_{w y}$ は溶着金属の降伏応力である.}

(c) 側面隅肉溶接部でなされる応力仕事 $W_{s w}$

図 $5(\mathrm{~b})$ 上り側面隅肉溶接部は長さ $D / 2$ にわたって塑性化するので, 単 位長さあたりの降伏耐力を ${ }_{s w} q_{y}$ とすると $W_{s w}$ は次式で表される.

$W_{s w}=2_{s w} q_{y} D \delta$

たたし，上式において，

$$
{ }_{s w} q_{y}=\sigma_{w y} \cdot s / \sqrt{6}
$$

\subsection{2 崩壊荷重}

崩壊機構 2,3 に基づいて得られる崩壊荷重 $P_{p, 2}, P_{p, 3}$ は仮想仕事の原 理より次式で表される。

$$
P_{p, 2}=\left(W_{c}+W_{d}+W_{f w}\right) / \delta
$$

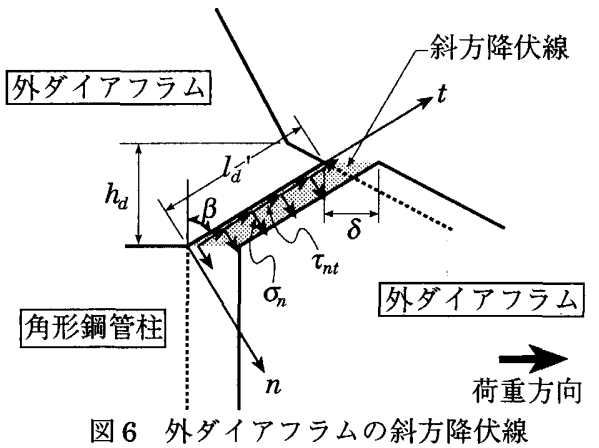

$$
P_{p, 3}=\left(W_{c}+W_{f w}+W_{s w}\right) / \delta
$$

上式の最小值を得るために次式を満足する $x, \kappa, \beta$ を求める必要がある.

$$
\frac{\partial P_{p i}}{\partial x}=0, \frac{\partial P_{p i}}{\partial \kappa}=0, \frac{\partial P_{p i}}{\partial \beta}=0 \quad(i=2,3)
$$

ただし，上式において(27.c)式は(26.a)式に適用するものとする.(27.c) 式より次式が得られる.

$$
\beta=\tan ^{-1}(3 \tan \theta)
$$

$(27 . \mathrm{a} \sim \mathrm{c})$ 式より得られる $x, \kappa, \beta$ を(26.a,b)式に代入すると, $P_{p, 2}, P_{p, 3}$ は 次式で表される.

$$
\begin{aligned}
P_{p 2}= & 2 \sigma_{d y} \cdot t_{d} \cdot h_{d}\left(\frac{3+\tan ^{2} \beta}{3}\right)^{0.5} \frac{1+\tan \theta}{1+\tan \theta \cdot \tan \beta}+\frac{4}{\sqrt{15}} \sigma_{u y} \cdot s\left(x+\frac{t}{2}\right) \\
& +\left\{\frac{t_{d}+2 s}{x}+\frac{D-t}{\kappa \cdot x}-\frac{2}{\kappa}+\frac{4}{\pi}\left(\log _{e} \kappa\right)^{2}+\pi\right\} \sigma_{c y} \cdot t^{2}
\end{aligned}
$$

$$
P_{p, 3}=\frac{4}{\sqrt{15}} \sigma_{w y} \cdot s\left(x+\frac{t}{2}\right)+\frac{2}{\sqrt{6}} \sigma_{w y} \cdot s D
$$

$$
+\left\{\frac{t_{d}+2 s}{x}+\frac{D-t}{\kappa \cdot x}-\frac{2}{\kappa}+\frac{4}{\pi}\left(\log _{e} \kappa\right)^{2}+\pi\right\} \sigma_{c y} \cdot t^{2}
$$
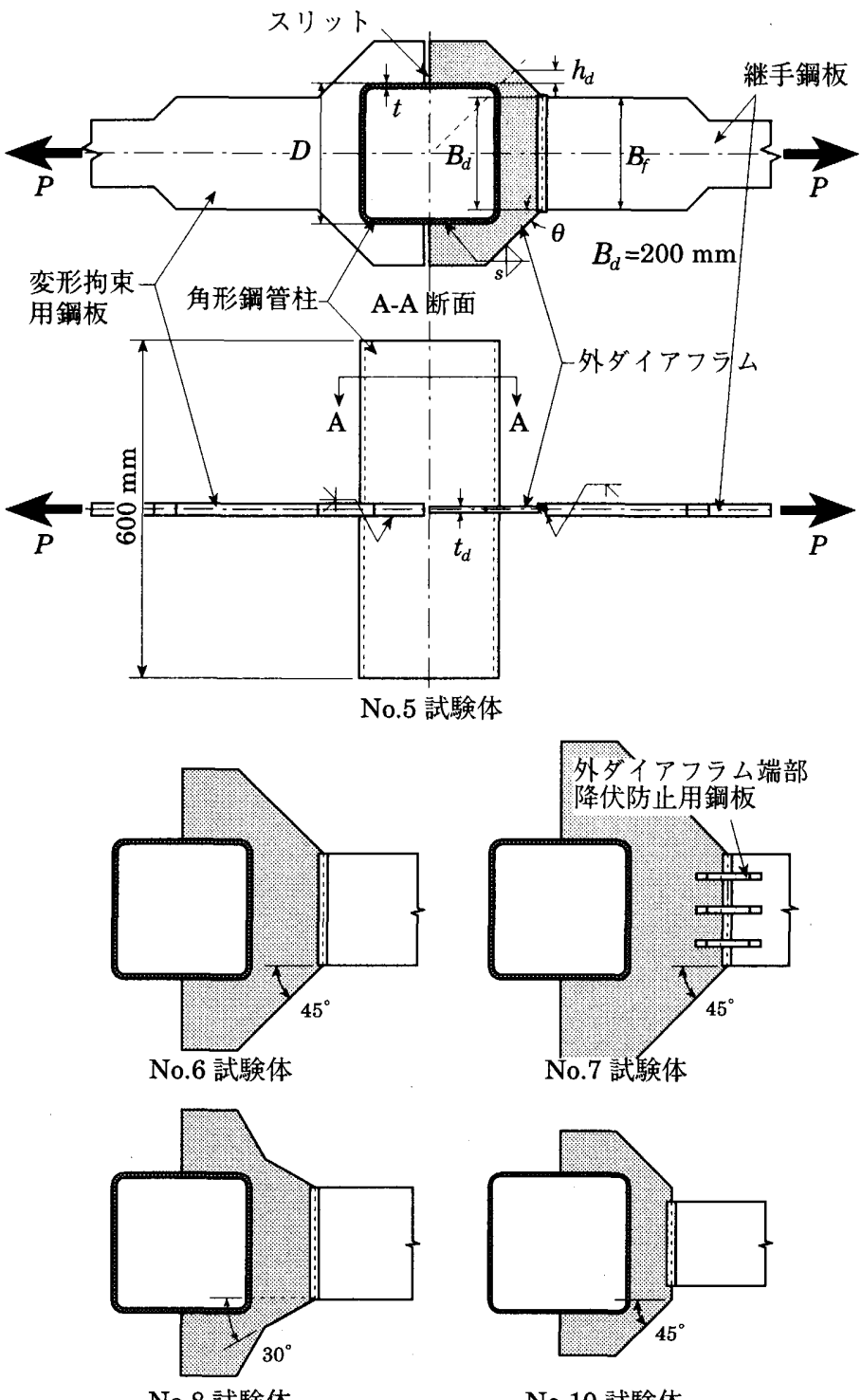

図 7 試験体図

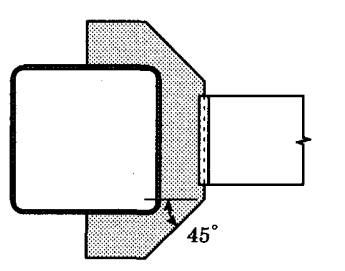

No.10 試験体 


\section{3. 接合部の局部引張実験}

本章では,前章で誘導した崩壊荷重および崩壊機構の検証を目的とし て,外ダイアフラム形式の角形鋼管柱と引張側梁フランジの接合部を取 り出した試験体を対象に局部引張実験を行う。

\section{1 実呀概要}

\subsection{1 試験体}

図 7 に試験体図，表 1 に試験体一覧，表 2 に鋼材の機械的性質，表 3 に溶着金属の機械的性質を示す.試験体数は 10 体で, 実験変数は鋼管 板厚, 外ダイアフラムせい・板厚, 水平ハンチ角度, 梁フランジ幅, 溶 接脚長である. 表1には, 材料試験結果を考慮した場合の各試験体に想 定される崩壊機構を示している. 図2の無応力状態を実現するために, 図7に示すようにスリットを設けている.図7の角形鋼管柱の中心線よ り右側の外ダイアフラムと角形鋼管柱が実験の対象となる部分であり， その他の部分については載荷途中で降伏しないように寸法㧍よび鋼種を 設定した. No.8試験体を除くすべての試験体は文献 7)の提案式の適用 範囲外である。

No.1, 5 10 試験体の溶接脚長を外ダイアフラム板厚の 0.7 倍にあ たる $9 \mathrm{~mm}$ とした. No.2 試験体は, 崩壊機構 3 (図 5(b)参照)の形成を 検証するために設定したものであり，溶接脚長を $5 \mathrm{~mm}$, 外ダイアフラ ムせいを 75mm とした. No.3 試験体は, 崩壊機構 2 (図 5(a)参照)の 形成を検証するために設定したものであり，溶接脚長を $5 \mathrm{~mm}$ とした。 また, No.4 試験体の溶接方法を図 8 に示寸異形隅肉溶接とし，等脚隅 肉溶接の脚長が外ダイアフラム板厚の 0.7 倍である場合の有効のど厚と 等しくなるように溶接脚長を設定した. No.4 試験体の積層要領は図 8 のとおり 3 層 4 パスであり，それ以外は 1 層 1 パスとした. 外ダイアフ ラムと角形鋼管柱の溶接は, 表 1 の溶接脚長を目標に同一の溶接工に よって施工された. その結果, No.1, 5 10 試験体の溶接脚長の平均 值は $10.3 \mathrm{~mm}$, No.2, 3 試験体では $6.1 \mathrm{~mm}$, No.4 試験体では $15.8 \mathrm{~mm}$ であった.すべての試験体の側面隅肉溶接は,外ダイアフラムの切断面 （スリット位置）までとし，スリット部に回さないようにした。なお，

表 1 試験体一覧

\begin{tabular}{|c|c|c|c|c|c|c|c|}
\hline \multirow{3}{*}{$\begin{array}{l}\text { 試 } \\
\text { 験 } \\
\text { 烋 } \\
\text { 䎹 }\end{array}$} & 角形鋼管柱 & \multicolumn{3}{|c|}{ 外ダイアフラム } & 溶接 & \multirow{3}{*}{$\begin{array}{c}\text { 梁フランジ } \\
\text { 幅 } \\
B_{f} \\
\mathrm{~mm}\end{array}$} & \multirow{3}{*}{$\begin{array}{l}\text { 崩 } \\
\text { 壊 } \\
\text { 機 } \\
\text { 構 }\end{array}$} \\
\hline & 外径 $\times$ 板厚 & せい & 板厚 & 水平ハンチ & 脚長 & & \\
\hline & $\begin{array}{c}D \times t \\
(D / t)\end{array}$ & $\begin{array}{c}h_{d}\left(h_{d} / D\right) \\
\mathrm{mm}\end{array}$ & $\begin{array}{c}t_{d} \\
\mathrm{~mm}\end{array}$ & $\begin{array}{c}\text { 角度 } \theta \\
\text { deg. }\end{array}$ & $\begin{array}{c}s \\
\mathrm{~mm}\end{array}$ & & \\
\hline 1 & \multirow{4}{*}{$\begin{array}{c}250 \times 12 \\
(21)\end{array}$} & $25(0.1)$ & \multirow{3}{*}{12} & \multirow{7}{*}{45} & 9 & \multirow{8}{*}{200} & 1 \\
\hline 2 & & 75.0 .32 & & & 5 & & 3. \\
\hline 3 & & \multirow{3}{*}{$25(0.1)$} & & & & & \\
\hline 4 & & & 28 & & 16 & & \\
\hline 5 & \multirow{4}{*}{$\underset{(28)}{250 \times 9}$} & & \multirow{5}{*}{12} & & \multirow{5}{*}{9} & & \\
\hline 6 & & $50(0.2)$ & & & & & \\
\hline 7 & & $75.0 .3)$ & & & & & 1 \\
\hline 8 & & \multirow{2}{*}{$25(0.1)$} & & 30 & & & \\
\hline$\frac{9}{10}$ & $\begin{array}{c}250 \times 6 \\
(42)\end{array}$ & & & 45 & & 150 & \\
\hline
\end{tabular}

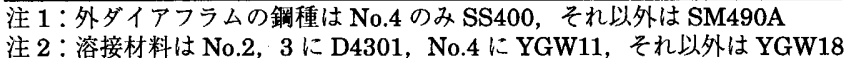

隅肉溶接の有効長さは一般に全長から溶接脚長の 2 倍 (始終端分) を差 し引くが, 次節での耐力計算においては，この始終端分を減じず,す心゙ ての試験体の側面隅肉溶接長を $D / 2$ としている。

\section{1 .2 載荷方法と計測方法}

$2000 \mathrm{kN}$ 万能試験機により, 試験体が最大耐力に到達するまで単調引 張載荷を行う．図 9 に示すように変位計を設置し，変位計から得られる 鋼管フランジの面外変形 $u$ を鋼管局部変形と定義する．また，鋼管フラ ンジ表面から $15 \mathrm{~mm}$ の位置の外ダイアフラム表面に1軸ゲージを貼付し， 荷重方向の歪分布を調べる。

\section{2 実験結果および考察}

\subsection{1 荷重一変形関係}

図 10 に各試験体の荷重一変形関係を示す. 図の縦軸は図 7 の荷重 $P$, 横軸は図 9 の鋼管局部変形 $u$ である. 図中のは、荷重一変形関係の接 線剛性が初期剛性の 3 分の 1 となるときの耐力 ${ }_{\text {exp }} P_{y,(1 / 3)}{ }^{4)}, \triangle$ は, $0.15 \%$ オフセット值により求めた酎力 ${ }_{e x p} P_{y,(0.15 \%)}$, 口は最大耐力 ${ }_{e x p} P_{u}$ である. ここで, $0.15 \%$ とは荷重一変形関係における残留変形の䤡管外径に対す る割合を表し， $\exp _{y,(0.15 \%)}$ は梁せいを鋼管外径の1.5倍とした時に鋼管局 部変形による梁端の残留回転角が $1 / 500 \mathrm{rad}$. に留まる荷重に相当する. (17), (29.a,b)式より得られる崩壊荷重 ${ }_{c a l} P_{p}$ を太実線で示す。また, 最 大耐力計算值 ${ }_{c a l} P_{u}$ を太点線で併記している. ${ }_{c a l} P_{u}$ の算出に際して, 崩壊 機構 1 の場合, (17)式の $\sigma_{c y}, \sigma_{d y}$ を $\sigma_{c u}$ (鋼管フランジの引張強さ), $\sigma_{d u}$ （外ダイアフラムの引張強さ）に置き換えた．崩壊機構 2 の場合, (29.a) 式の $\sigma_{w y}$ のみ $\sigma_{w u}$ (溶着金属の引張強さ）に置き換え，鋼管フランジと外 ダイアフラムについては $\sigma_{c y}, \sigma_{d y}$ を用いた．崩壊機構 3 も同様に(29.b) 式の $\sigma_{w y}$ のみ $\sigma_{w u}$ に置き換えた.これは, 最大耐力に達したときのNo.2, 3 試験体の鋼管局部変形が他の試験体に比べて小さいので, 最大耐力時 には銅管フランジと外ダイアフラムは引張強さに達していないものと判 断したためである。図 10 より ${ }_{\text {exp }} P_{y,(1 / 3)},{ }_{\exp } P_{y,(0.15 \%)}$ 時の鋼管局部変形は 試験体によらず 0.5 1mm程度であり，鋼管板厚に対して5～10\%程 度である. ${ }_{c a l} P_{p}$ 時の鋼管局部変形は $1 \sim 3 \mathrm{~mm}$ 程度であり(ただし, No.2, 3 試験体を除く)，鋼管局部変形が急激に進展しはじめる付近の耐力を 捉えている. ${ }_{\text {exp }} P_{u}$ 時に関しては, No.2, 3 試験体が他の試験体に比べて 著しく鎆管局部変形が小さいこと, No.8試験体の鋼管局部変形がNo.5 試験体に比べて著しく大きいことが挙げられる.

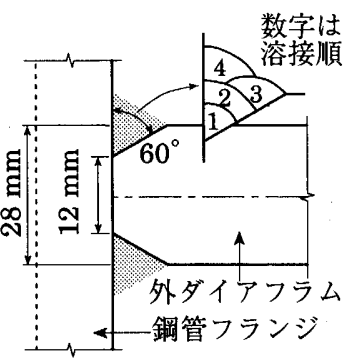

図 8 異形隅肉溶接
表 2 鋼材の機械的性質

\begin{tabular}{|c|c|c|c|c|c|c|c|c|}
\hline 鋼種 & $\begin{array}{c}\text { 衣 } 2 \\
\text { 板厚 } \\
\mathrm{mm}\end{array}$ & $\begin{array}{l}\text { 降伏点 } \\
\mathrm{N} / \mathrm{mm}^{2}\end{array}$ & $\begin{array}{c}\text { 引張強さ } \\
\mathrm{N} / \mathrm{mm}^{2}\end{array}$ & $\begin{array}{c}\text { 破断伸び } \\
\%\end{array}$ & $\begin{array}{c}\text { 溶接脚長 } \\
\mathrm{mm}\end{array}$ & $\begin{array}{l}\text { 降伏点 } \\
\mathrm{N} / \mathrm{mm}^{2}\end{array}$ & $\begin{array}{l}\text { 引張強さ } \\
\mathrm{N} / \mathrm{mm}^{2}\end{array}$ & $\begin{array}{c}\text { 破断伸び } \\
\%\end{array}$ \\
\hline SM490A & 12 & 363 & 516 & 27 & 5 & 496 & 557 & - \\
\hline SS400 & 28 & 258 & 425 & 33 & 9 & 542 & 616 & - \\
\hline \multirow{3}{*}{ BCR295 } & 6 & 374 & 454 & 37 & 16 & 481 & 579 & 29 \\
\hline & 9 & 400 & 469 & 36 & \multirow{2}{*}{\multicolumn{4}{|c|}{ 注：降伏点はすべて $0.2 \%$ オフセット法による }} \\
\hline & 12 & 383 & 441 & 39 & & & & \\
\hline
\end{tabular}

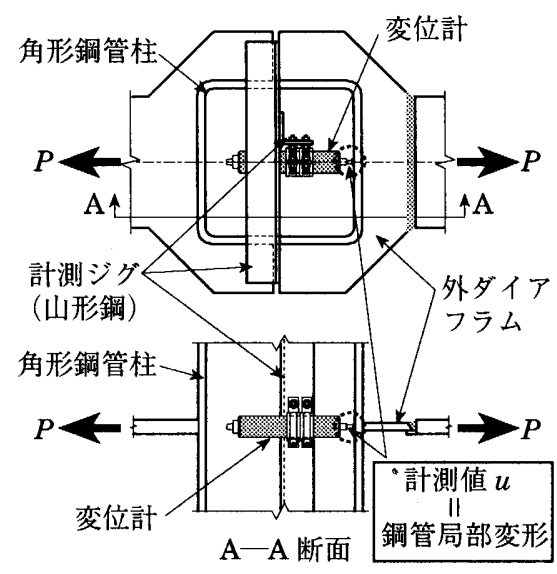

図 9 変位計設置方法と 鋼管局部変形の定義 


\subsection{2 耐力の実験值と計算值}

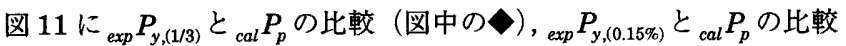

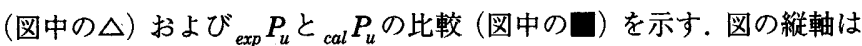
実験値と計算値の比，横軸は試験体番号である。

崩壊機構 1 を形成する試験体 (No.1, 4 10) の場合, ${ }_{\text {exp }} P_{y,(1 / 3)}$ は ${ }_{c a l} P_{p}$ の 70〜80\%程度, ${ }_{e x p} P_{y,(0.15 \%)}$ は ${ }_{c a l} P_{p}$ の 80〜100\%程度を示している. 実 験結果を過大評価する要因として,外ダイアフラムの面内剛性に比べて 鋼管フランジの面外剛性が小さいので ${ }_{\text {exp }} P_{y,(1 / 3)}$ exp $_{\text {exp }} P_{y,(0.15 \%)}$ 時における 鋼管局部変形に対して, 外ダイアフラムは崩壊機構に到達しているが, 鋼管フランジは崩壊機構に到達していないことが挙げられる。

これを锥付ける一例として図 12 を示す. 図 12 は鐦管幅厚比 $D / t$ を 変化させたNo.1，5，9試験体の荷重一変形関係であり，鋼管局部変形 $u=2 \mathrm{~mm}$ まで示されている. 図中の太実線は, 鋁管フランジの応力仕事 を無視した崩壊荷重, すなわち ${ }_{c a l} P_{p}-W_{c} / \delta$ を表しており, 破線と太実 線の差が鎆管フランジの崩壊荷重に対する寄与分である。

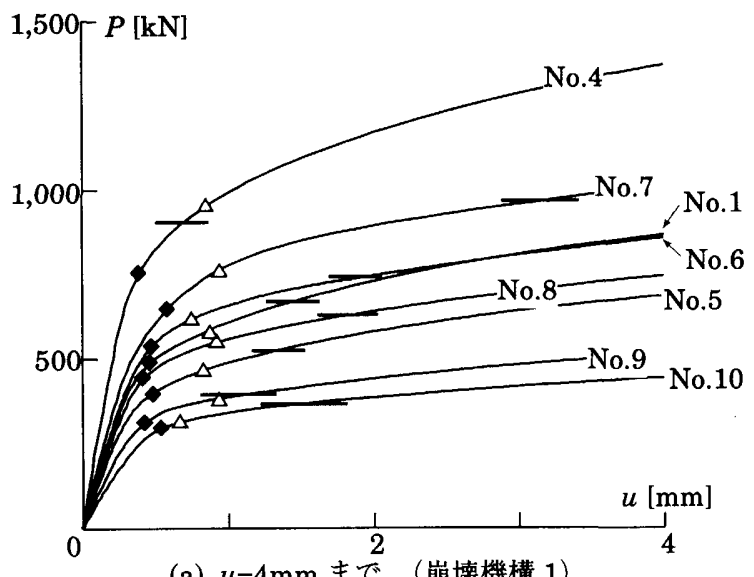

(a) $u=4 \mathrm{~mm}$ まで（崩壊機構 1)

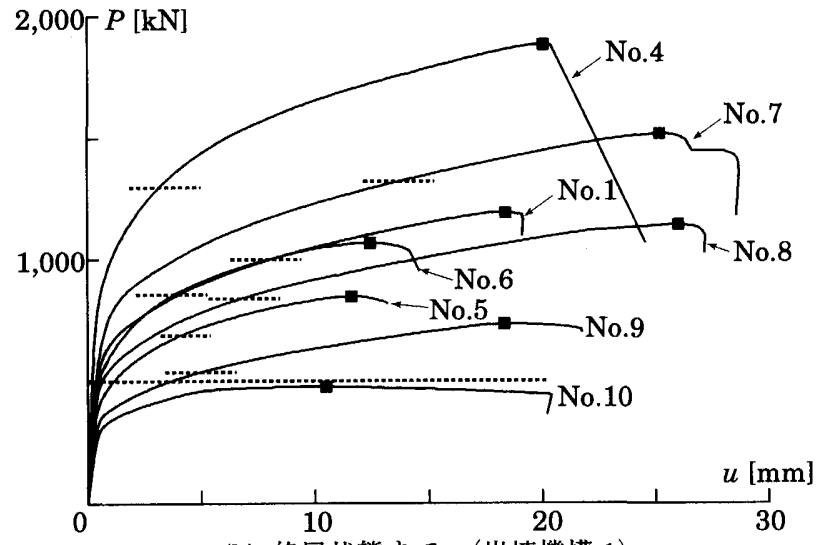

（b）終局状態まで（崩壊機構 1）

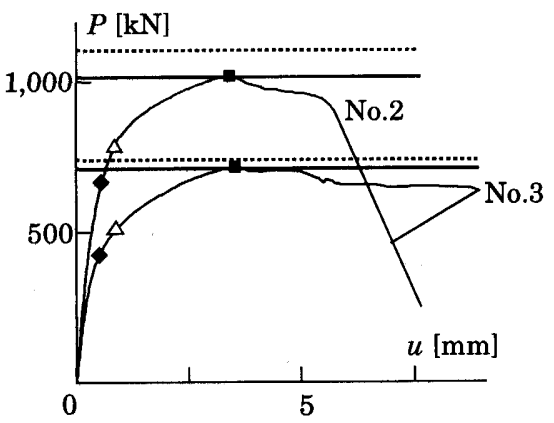

(c) 終局状態まで（崩壊機構 2,3）

図 10 荷重一変形関係 $\left(_{c a l} P_{p}-W_{c} / \delta\right) /_{\exp } P_{y,(1 / 3)}$ は, No.1試験体が 0.73, No.5試験体が 0.81 , No.9 試験体が 0.96 を示しており，いずれも ${ }_{e x p} P_{y,(1 / 3)}$ は ${ }_{c a l} P_{p}-W_{c} / \delta_{\text {cal }} P_{p}$ の 間に位置するとともに，鋼管幅厚比 $D / t$ が大きいほど, ${ }_{c a l} P_{p}-W_{c} / \delta$ に 近づく，これは，鋼管フランジの面外曲げ風性が小さくなるにしたが い, ${ }_{\text {exp }} P_{y,(1 / 3)}$ 時の鋼管局部変形量に対して, 鋼管フランジの面外曲げに よる応力伝達が期待できなくなることを意味している.

次に, exp $P_{y,(1 / 3)}$ 時に外ダイアフラムがほほ崩壊機構に到達しているこ とが確認できる例として図 13 を示す。図 13 はNo.1，5，9試験体の外 ダイアフラムに貼付した 1 軸ゲージより得られた歪分布である。○は

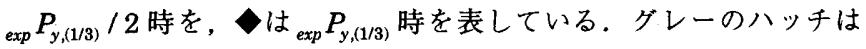
$(16 . a, b)$ 式より得られる $x+t / 2$ の範囲を表している. $x+t / 2$ の範囲に扔い $\tau_{\text {exp }} P_{y,(1 / 3)} / 2$ 時の歪は弾性域に留まっているが, ${ }_{\text {exp }} P_{y,(1 / 3)}$ 時の歪は降伏 歪を超えているものが大部分である。したがって, ${ }_{\text {exp }} P_{y,(1 / 3)}$ 時の鋼管局 部変形に対して外ダイアフラムは降伏場を形成し，その範囲は(16.a,b) 式で予測した範囲とほほ一致することがわかる.

一方, ${ }_{c a l} P_{u}$ は ${ }_{\text {exp }} P_{u}$ に対して, 試験体（No.1，4～9）に関して 10\%以 上の過小評価を, No.10試験体に関して 7\%の過大評価を与えている.

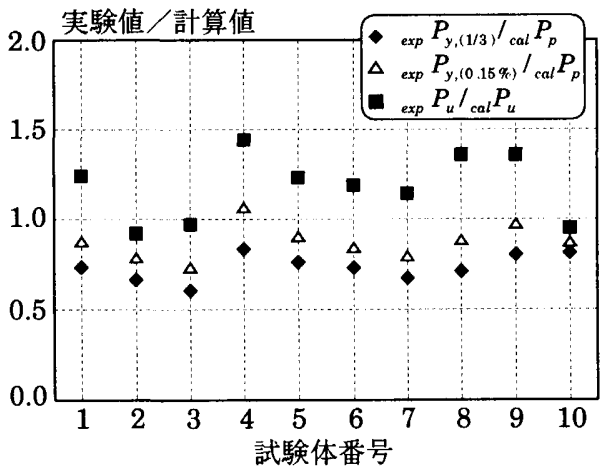

図 11 実験値と計算値の比較
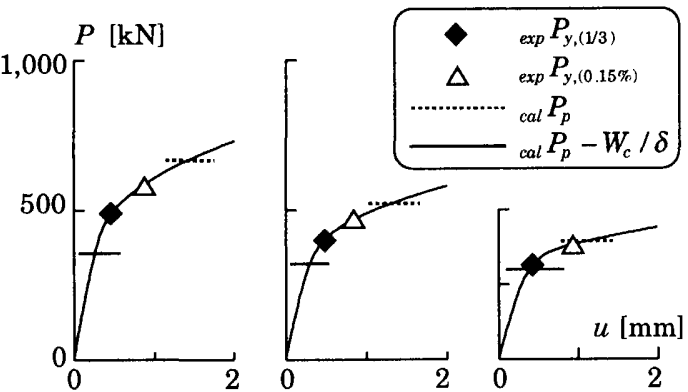

(a) No.1 試験体 (b) No.5 試験体 (c) No.9 試験体 図 12 荷重一変形関係

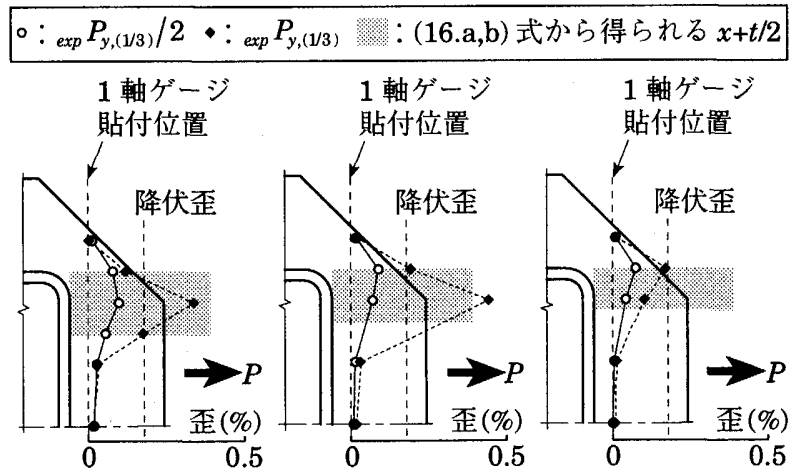

(a) No.1 試験体

(b) No.5 試験体 (c) No.9 試験体

四 13 外ダイアフラムの歪分布 
特にNo.4 試験体については 44\%, No.8, 9試験体については36\%の過 小評価となり，実験值との差は大きい。試験体（No.1，4～9）に対し て過小評価を与える一因として,最大耐力時には鋼管局部変形がかなり 進行しているため, 鋼管フランジには曲げ応力のみならず引張応力も生 じることになり，その結果耐力上昇が大きくなることが挙げられる。な お, No.10 試験体に対して過大評価を与えるのは, 梁フランジ幅 $B_{f}$ が 外ダイアフラム幅 $B_{d}$ よりも小さく, 外ダイアフラムと梁フランジが入 り隅を形成するため,外ダイアフラムと梁フランジの溶接部の始終端に 歪集中が発生し, 比較的早期に溶接部に延性亀裂が生じ, 最大耐力が亀 裂の進展によって決まったためである. 図10のNo.9試験体とNo.10試 験体の荷重一変形関係を比較すると, No.10試験体の2次勾配が著しく 小さいのは，この亀裂の進展に起因しているためである.

外ダイアフラムと角形鋼管柱との隅肉溶接部が降伏する崩壊機構 2 , 3 を形成する試験体 (No.2, 3) の場合, ${ }_{\text {exp }} P_{y,(1 / 3)}$ および ${ }_{\text {exp }} P_{y,(0.15 \%)}$ は ${ }_{c a l} P_{p}$ の $60 \sim 65 \%$ 程度および $75 \sim 80 \%$ 程度となり, 崩壊機構 1 の場合に比

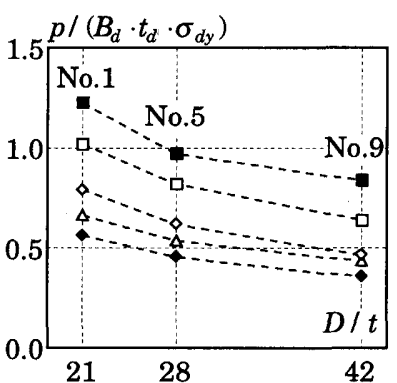

(a) $D / t$

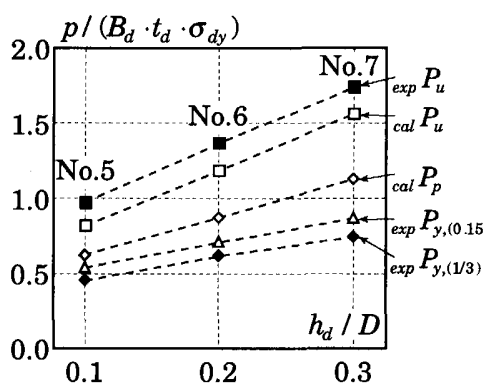

(b) $h_{d} / D$
図 14 各耐力と奏験変数の関係
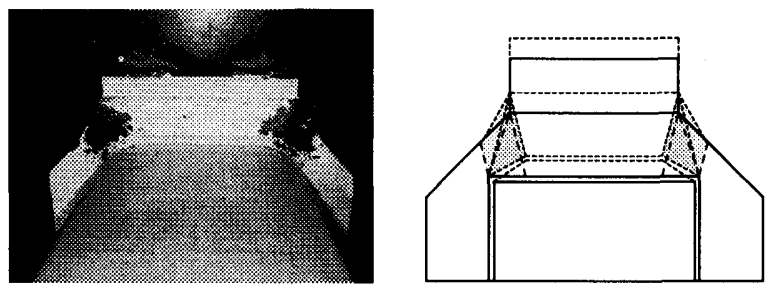

(a) No.9 試験体
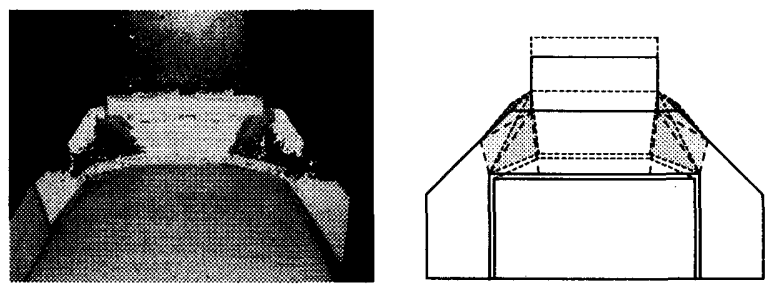

(b) No.10 試験体

図 15 終局状態と崩壊機構 1 の比較

外ダイアフラムの降伏領域

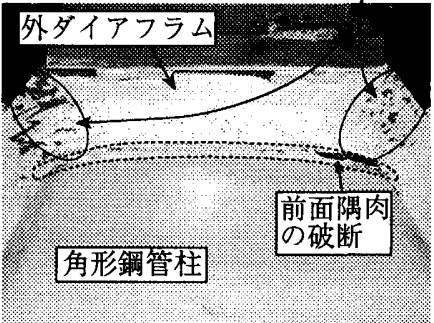

(a) No.3 試験体

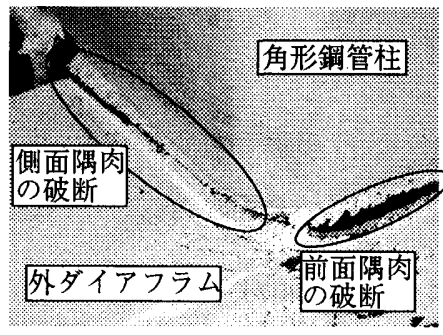

(b) No.2 試験体
図 16 No.2，3 試験体の終局状態
ベて若干過大評価する割合が大きくなるが, ${ }_{\text {exp }} P_{u}$ は ${ }_{c a l} P_{u}$ の $92 \%, 97 \%$ であり, 3.2.1 項で仮定した最大耐力時の材料強度の設定が概ね妥当で あると判断できる。

10 体の試験体のうち, $D / t$ を変化させた試験体 $($ No. $1,5,9)$ と $h_{d} / D$ を変化させた試験体（No.5～7）について，各耐力と実験変数の関倸 を図 14 に示す。縦軸は各耐力 $\left(p\right.$ とする)を $B_{d} \cdot t_{d} \cdot \sigma_{d y}$ で無次元化した ものであり，横軸は(a) $D / t$, (b) $h_{d} / D$ である. いずれの場合も実験変 数の変化に伴う耐力の变化に対して,計算值は実験值の傾向をよく捉え ている.

\subsection{3 終局状態と崩壇機構}

図 15 にNo.9, 10 試験体の終局状態と図 3 の崩壊機構 1 を比較して 示す.いずれの試験体についても,外ダイアフラムの塑性化状況が想定 した崩壊機構と良く対応していることが確認できる.また,ここには示 していないが他の試験体（No.1, 4８）についても想定どおりの崩壇 機構を呈することを確認した.

No.2, 3 試験体の終局状態を図 16 に示す.No.2 試験体は，側面隅肉 溶接部の終端部 (スリット部)に亀裂が発生し，その後側面隅肉溶接部 から前面隅肉溶接部にかけて脆性的に破断が発生することにより終局を 迎えた. No.3 試験体は，外ダイアフラムの塑性化が進展し最大耐力を 迎えた後, 鋼管角部の歪集中により前面隅肉溶接部が脆性破断して終局 を迎えた．以上のことから No.2，3 試験体に関しても，想定どおりの 崩壊機構を確認できたと言える。

4. まとめ

本研究では, 外ダイアフラム形式角形鋼管柱梁接合部を対象として, 溶接接合部も含む任意の接合部寸法に適用できる耐力式を構築するため に, 外ダイアフラムに一様歪の三角形要素を導入して塑性解析を行っ た.また耐力式の妥当性を確認するために,外ダイアフラム形式の角形 鋼管柱と引張側梁フランジ接合部の局部引張実験を実施し,以下の結果 を得た。

1) 崩壊機構 1 を形成する試験体 (No.1, 4 10) の ${ }_{c a l} P_{p}$ は, exp $P_{y,(1 / 3)}$ に 対して 70〜80\%, exp $P_{y,(0.15 \%)}$ に対して $80 \sim 100 \%$ をした.このよ うに ${ }_{\text {exp }} P_{y,(1 / 3)},{ }_{\exp } P_{y,(0.15 \%)}$ を過大評価する一因として, ${ }_{\exp } P_{y,(1 / 3)}$, ${ }_{\exp } P_{y,(0.15 \%)}$ 時において面外剛性の低い鋼管フランジが崩壊機構に到 達していないことが挙げられる。

2) 崩塆機構 1 を形成する試験体（No.1，4～9）の ${ }_{c a l} P_{u}$ は, ${ }_{\text {exp }} P_{u}$ を 14 〜 44\%下回った.これは, ${ }_{\text {exp }} P_{u}$ 時における鋼管フランジの面外変形 が大きく,鋼管フランジは曲げ応力のみならず引張応力にも抵抗し ているためであると考えられる。一方，No.10試験体については， 早期に外ダイアフラムと梁フランジ溶接部始終端から外ダイアフラ ム側に亀裂が進展し，exp $P_{u}$ をわずかに過大評価する結果となった。

3) 崩壊機構 2,3 を形成する試験体 (No.2,3）の ${ }_{c a l} P_{u}$ は, ${ }_{\text {exp }} P_{u}$ と良い 対応を示した.このことからも, ${ }_{\text {exp }} P_{u}$ 時の鋼管フランジや外ダイア フラムの応力は降伏応力レベルに留まっているものと考えられる. 4)すべての試験体で,想定どおりの崩壊機構形成が確認できた.また, 崩壊機構 1 を形成する試験体（No.1，4～10）に対して，外ダイア フラムは ${ }_{\text {exp }} P_{y,(1 / 3)}$ 時に概ね崩壊機構に到達していることを確認した. 本論では,外ダイアフラム形式角形鋼管柱梁接合部の降伏耐力実験值 $\left({ }_{\text {exp }} P_{y,(1 / 3)}, e_{\text {exp }} P_{y,(0.15 \%)}\right)$ と崩壊荷重計算値 ${ }_{c a l} P_{p}$ の対応関係について述べ たが, 降伏耐力を精度良く評価するには到っていない. 降伏耐力の評価 
式については，さらに検討が必要である、また， $P_{p, 1}$ を求めるには,(16) 式を数值計算により解く必要がある. したがって,(16)式を解くことな く $x$ および $\kappa$ を簡便な式で与えることにより $P_{p, 1}$ を陽な形で提示するこ とが望まれる。これらに関して今後の課題としたい.

\section{謝辞}

（社）日本鉄鋼連盟より実験用鋼材の支給を賜りました，試験体製作に あたっては，竹島鉄工建設株式会社 竹島徹氏より数々のご協力を得ま した。また本研究を進めるにあたり，神戸大学田渕基嗣教授に貴重な ご意見をいただきました．実験の遂行に際しては，京都大学 馨高裕治 助手に多大な協力を賜りました．ここに感謝の意を表します。

\section{参考文献}

1）日本建築学会近畿支部鉄骨構造部会：1995年兵庫県南部地震鉄骨造建物被害 調查報告書, 1995.5

2）山成實, 小川厚治, 黒羽啓明, 海原広幸：外ダイアフラム接合部の有限要素 解析による剛性評価式 (半剛接銅骨組柱梁仕口の復元力特性に関する研究), 構造工学論文集, Vol.38B, pp.475-484, 1992.3

3）上場輝康，汇見卓郎：外ダイアフラム補剛形式角形鋼管柱一梁接合部の局部 変形挙動に関する研究 (その2. 局部変形挙動のモデル化), 日本建築学会大 会学術講演梗概集（東北），C-1，構造 III，pp.625-626，2000.9

4）田㴊基嗣，金谷弘，上場惮康：角形銅管・H形はり接合部の局部破壊一角形 鋼管柱溶接接合部の実験的研究 1 - , 日本建築学会構造系論文報告集, 第 349 号, pp.71-79, 1985.3

5）田㴊基嗣，金谷弘，上場輝康：角形銅管・ $\mathrm{H}$ 形はり接合部の局部耐力推定式 一角形鋼管柱溶接接合部の実呀的研究 $2-$, 日本建築学会構造系論文報告集, 第 352 号, pp.79-89, 1985.6

6) 森田耕次, 江波戸和正, 渡辺仁, 山本昇，安田博利，里見孝之：箱形断面朴 - H形断面はり接合部のダイアフラム補强に関する研究一接命部降伏付ノのの 評価一, 日本建築学会構造系論文報告集，第 388 号，pp.100-111，1988.6

7）日本建築学会：鋼管構造設計施.工指針·同解説，1990

8）瀧正哉, 久保田淳, 藤村博, 荻原行正, 福元敏之：分割外タイアフラム形式 を用いたコンクリート充填解形銅管柱・铁骨梁接合部の実験的研究（その 1 中柱形式の接合部局部门張実験)，日本建築学会大会学術講演梗概集（北海 道), C-1, 構造 III, pp.1103-1104, 2004.8

9) O.C.ツイエンキーヴィッツ, Y.K.チューン共著, 吉識雅夫監訳：マトリック 有限要素法, 3 章, pp.30-33, 1970.3

10) E.H.Mansfield : Studies in collapse analysis of rigid-plastic plates with a square yield diagram, Proc. of the Royal Society London, 241, Series A, pp.311-338, 1957.8

11) 安井信行, 吹田啓一郎, 井上一朗: 斜方隅肉溶接継目の破壊機構と最大耐力, 日本建築学会構造系論文集，第 579 号, pp.111-118, 2004.5

付録 A 崩壊機構 1 の領域 IIにおける応力仕事 ${ }_{\mathrm{III}} W_{d}$ について

領域 I, II の場合と同様の手続きを行うことにより，領域 III の応力 仕事 ${ }_{\mathrm{III}} W_{d}$ は次式で得られる.

$$
\begin{aligned}
{ }_{\mathrm{III}} W_{d} & =2 \frac{E_{1} \xi_{1}^{2}+E_{2} \xi_{1}+E_{3}}{\left(D_{1} \xi_{1}^{2}+D_{2} \xi_{1}+D_{3}\right)^{0.5}}\left(a-l_{d} \sin \alpha\right) t_{d} \sigma_{d y} \delta \\
& =2 \frac{E_{1}{ }^{\prime} \xi_{1}^{2}+E_{2}{ }^{\prime} \xi_{1}+E_{3}{ }^{\prime}}{\left(D_{1}{ }^{\prime} \xi_{1}^{2}+D_{2}{ }^{\prime} \xi_{1}+D_{3}{ }^{\prime}\right)^{0.5}}\left(a-l_{d} \sin \alpha\right) t_{d} \sigma_{d y} \delta
\end{aligned}
$$

ただし，上式において，

$$
\begin{aligned}
& D_{1}=\left(18+27 C_{1}^{2}\right) \xi_{2}^{2}+197 C_{1} \xi_{2}+18 C_{1}^{2}+243 \\
& D_{2}=\left(-54 C_{1}-27 C_{2}\right) \xi_{2}-36 C_{1} C_{2}-162 \\
& D_{3}=18 C_{2}^{2}+27 \\
& D_{1}{ }^{\prime}=\left(18+27 C_{1}^{2}\right) \xi_{1}^{2} \\
& D_{2}{ }^{\prime}=197 C_{1} \xi_{1}^{2}+\left(-54 C_{1}-27 C_{2}\right) \xi_{1} \\
& D_{3}{ }^{\prime}=\left(18 C_{1}^{2}+243\right) \xi_{1}^{2}+\left(-36 C_{1} C_{2}-162\right) \xi_{1}+18 C_{2}^{2}+27 \\
& E_{1}=3 C_{1}^{2} \xi_{2}^{2}+14 C_{1} \xi_{2}+4 C_{1}^{2}+9 \\
& E_{2}=\left(-5 C_{1}-2 C_{2}+4\right) \xi_{2}-8 C_{1} C_{2}+2 C_{1}-12 \\
& E_{3}=4 C_{2}^{2}-2 C_{2}+3 \\
& E_{1}{ }^{\prime}=3 C_{1}^{2} \xi_{1}^{2} \\
& E_{2}{ }^{\prime}=14 C_{1} \xi_{1}^{2}+\left(-5 C_{1}-2 C_{2}+4\right) \xi_{1} \\
& E_{3}{ }^{\prime}=\left(4 C_{1}^{2}+9\right) \xi_{1}^{2}+\left(-8 C_{1} C_{2}+2 C_{1}-12\right) \xi_{1}+\left(4 C_{2}^{2}-2 C_{2}+3\right) \\
& C_{1}=\left(b+l_{d} \cos \alpha\right) /\left(a-l_{d} \sin \alpha\right) \\
& C_{2}=\left(c+l_{d} \cos \alpha\right) /\left(a-l_{d} \sin \alpha\right)
\end{aligned}
$$

(A1.a,b)式を考慮すると(14)式は厳密には次のように表される.

$$
P_{p, 1}=\left({ }_{\mathrm{I}} W_{d}+{ }_{\mathrm{II}} W_{d}+{ }_{\mathrm{III}} W_{d}+W_{c}\right) / \delta
$$

したがって,(A4)式を最小化するためには $(15 . \mathrm{a} \sim \mathrm{c})$ 式に加えて次式を 満足する必要がある。

$$
\frac{\partial P_{p, 1}}{\partial \xi_{1}}=0, \frac{\partial P_{p, 1}}{\partial \xi_{2}}=0
$$

$(\mathrm{A} 5 . \mathrm{a}, \mathrm{b})$ より次式が得られる.

$$
\begin{array}{r}
2 D_{1} E_{1} \xi_{1}^{3}+3 D_{2} E_{1} \xi_{1}^{2}+\left(4 D_{3} E_{1}+D_{2} E_{2}-2 D_{1} E_{3}\right) \xi_{1}+2 D_{3} E_{2}-D_{2} E_{3}=0 \\
2 D_{1}^{\prime} E_{1}{ }^{\prime} \xi_{2}^{3}+3 D_{2}{ }^{\prime} E_{1}{ }^{\prime} \xi_{2}^{2}+\left(4 D_{3}{ }^{\prime} E_{1}{ }^{\prime}\right. \\
\left.+D_{2}{ }^{\prime} E_{2}{ }^{\prime}-2 D_{1}{ }^{\prime} E_{3}{ }^{\prime}\right) \xi_{2} \\
+2 D_{3}{ }^{\prime} E_{2}{ }^{\prime}-D_{2}{ }^{\prime} E_{3}{ }^{\prime}=0 \quad(\mathrm{~A} 6 . \mathrm{a}, \mathrm{b})
\end{array}
$$

$(\mathrm{A} 6 . \mathrm{a}, \mathrm{b})$ 式より得られる $\xi_{1}, \xi_{2}$ と $(15 . \mathrm{a} \sim \mathrm{c})$ 式より得られる $x, \kappa, \alpha を(14)$ 式に代入して, 最終的な崩壊荷重の数式表現が得られることになるが, (A6.a,b)式より $\xi_{1}, \xi_{2}$ を得ることは非常に困難である. 一方, 本文で述

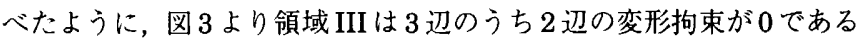
ため, ${ }_{\text {III }} W_{d}$ の最小值は非常に小さいものと考えられる。 そこで ${ }_{\mathrm{III}} W_{d}$ が $W_{i n}$ に占める割合の一例を図A1に示す. 縦軸に ${ }_{\mathrm{III}} W_{d} / W_{i n}$, 横軸に $t_{d} / t$ をとり，パラメータとして $D=200,300,400,500 \mathrm{~mm}, \theta=30^{\circ}, 45^{\circ}$ を採用した. なお，図 $\mathrm{A} 1$ は $a / D=0.3, b / D=0.25, B_{d} / D=0.8\left(B_{d}\right.$ : 外 ダイアフラムの幅), $D / t=10$ のきの結果である. 図 $\mathrm{A} 1$ より, いずれ にしても ${ }_{\text {III }} W_{d}$ は非常に小さく, 無視できる. 以上のことを考慮して, 本 文では(16)式を用いることとした。

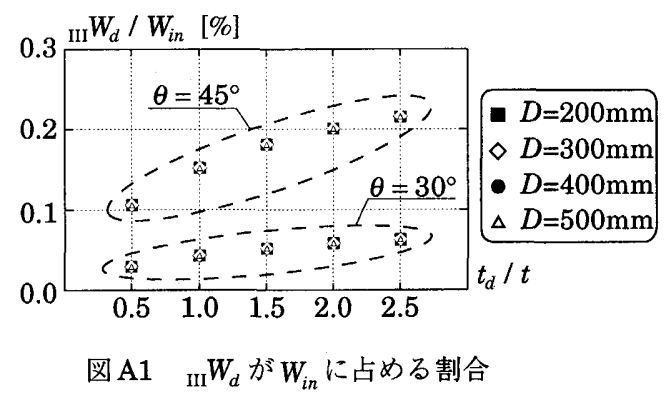

(2006年 1 月 10 日原稿受理, 2006 年 4 月 14 日採用決定) 